\title{
Variations in the Susceptibility of some Potato (Solanum tuberosum L.) Cultivars to Infestation with Certain Piercing Sucking Insect Pests Darwish, A. A. E. \\ Plant Protection Department, Faculty of Agriculture, Damanhour University, Egypt adnan.darwish@damanhour.edu.eg
}

\section{ABSTRACT}

Potato (Solanum tuberosum L.) is an economically important vegetable crop all over the world. The piercing sucking insect pests are serious pests threatening potato plantations in many countries. The present investigation contributes to the knowledge in the susceptibility of certain potato cultivars to infestation with these insects in Beheira Governorate, Egypt. Five global potato cultivars currently used in Egypt's potato production were evaluated through two successive seasons (summer plantations) in field experiments for their susceptibility to sucking insect infestation. The experiment was designed in a completely randomized block design and all data were analyzed using the SAS $®$ program. None of the tested potato cultivars was immune or highly resistant to the tested insect pests. The cultivars Banba and Diamante were found quite resistance to piercing sucking insect pests. The cultivar Herms was found as moderately susceptible while Spunta and Cara were found to be the most susceptible cultivars. The green lacewing, Chrysoperla carnea; seven-spotted lady beetle, Coccinella septempunctata; eleven spotted lady beetle, Coccinella undecimpunctata and the pirate bug, Orius sp are the most important predators which associated with the sucking insects pests on the potato cultivars.

Keywords: Potato, Sucking insect pests, Aphids, Thrips, whitefly, Natural enemies.

\section{INTRODUCTION}

The potato (Solanum tuberosum L.) is the third most important world crop, after rice, and wheat (Visser, et al. 2009). It is a major source of energy, contains high levels of carbohydrate, mineral and significant amounts of vitamins B and C (Abdel-Aal, et al., 1977). Potato as an economic crop has been attacked by several pests especially piercing sucking insect pests. These insects are a major pests on the vegetable plants for their direct damages that are caused by the insect feeding on the plants and/or the indirect damages as a virus vector to these planting materials. Many researchers investigated the sucking insect pests and reported that the whitefly, Bemisia tabaci (Gennadius); the green peach aphid, Myzus persicae (Sulzer), potato leaf hopper, Empoasca discipiens (Paoli) and the onion thrips, Thrips tabaci Lindeman attacked potato plants just after the first appearance of seedlings until harvesting date (Mogahed, 2000; El-khawas and Shoeb, 2004; Musa, et al. 2004, Saguez et al. 2005; Saguez et al., 2010; Fernandes and Fernandes, 2015; Mogahed, 2015; and D'Auria et al., 2016). The whitefly, B. tabaci has a high reproductive capacity and destructive life habits in addition to feeding on more than 700 host plant species (Greathead, 1986). The leafhopper, Empoasca sp., usually associated with potato crop and many other crops around the world (Lamp et al., 1994). Aphids are among the most destructive pests on potato plants in the temperate regions (Nderitu and Mueke, 1986) as a vector for the many of plant viruses. The green peach aphid is represents one of the major insect pests affecting potato production, it is distributed worldwide and feeding on over than 400 species of host plants (Raman, 1984; Hooker, 1986, Cloyd et al., 1998). The control of piercing sucking insect pests in several crops has become a challenge to growers, because the damages caused by these insects have increased in various countries (including Egypt). The host plant resistance and natural enemies are very important components of any strategy of pest management. The breeding of plants for insect resistance has not been as advanced as has been in disease resistance breeding therefore the cultivars that were able to withstand the insect pests are very important, and it is considered the ideal method (Sharma and Ortiz, 2001). So, the present study was carried out to evaluate the susceptibility of five cultivars with respect to piercing sucking insect pest's infestation under the field conditions. Also, the study aims to determine the existence of beneficial insect species that associated with the potato piercing sucking insect pest populations

\section{MATERIALS AND METHODS}

The present study was conducted at private farm in Abu El Matamir district Beheira Governorate, Egypt in summer plantation (the tubers were sown in Mid-January, 2017 and 2018 years). An area of about halfe feddan was divided into 20 equal plots comprised the five cultivars (Herms, Diamante, Banba, Spunta and Cara) of potato of 4 replicates each at an inter-row distance of $75 \mathrm{~cm}$ and an intra-row distance of $25 \mathrm{~cm}$. The experiment was designed in a completely randomized block design and the plots were separated by one meter non-cropped area. All plots received the normally recommended agricultural and kept free from any insecticidal application.

After five weeks from the sowing, samples of 40 leaves/ cultivar (10 leaves from each plot) were randomly selected and direct counts of Bemisia tabaci (adults) and Empoasca decipiens (adults), were carefully done in the early morning (when insects were less active) on both surfaces of these leaves. Also, the predators that associated with such insect pests were counted directly in the fields (in ten whole plants from each plot). Then, the investigated samples were picked and placed into paper bags and transferred to the laboratory for examine B. tabaci (nymphs), E. decipiens (nymphs), Myzus persicae, Aphis gossypii, Thrips tabaci (adults and nymphs) by the aid of stereoscopic microscope. Sampling continued until the crop harvest. The analysis of variance (F-test) was adopted and the L.S.D values were used to determine the significance between means of cultivars for both insect species and natural predators (SAS Statistical software, 1999).

\section{RESULTS AND DISCUSSION}

Data presented in Tables (1\&2) showed that, the means of weekly numbers of (adults and nymphs) whitefly, onion thrips, leafhopper, cotton aphid and green peach aphid through the whole season on the leaves of five cultivars of potato plants namely, Herms, Diamante, Banba, Spunta and Cara. None of the tested potato cultivars was immune or highly resistant to the tested sucking insect pests. However, the different tested cultivars of potato showed different resistance capacity against piercing sucking insect pests. 
The obtained results in Table (1) and illustrated in Fig. (1) indicated that, among the different potato cultivars, Cara recorded the highest attraction of whitefly, B. tabaci with mean numbers of 8.89 individuals/ leaf which was significant $(P>0.05)$ than Banba (4.68 individuals/ leaf), and Diamante (3.6 individual/leaf) and insignificance with Spunta (7.91 individuals/ leaf) and Herms (8.76 individuals). Regarding to the onion thrips, T. tabaci, the L. S. D value was 0.44 , accordingly there is no significant differences between Spunta cultivar and the four cultivars; Cara, Banba, Herms and Diamante. The lowest mean numbers of thrips /leaf were recorded in Diamante (0.44 individuals) while the highest mean of thrips /leaf was recorded in Spunta cultivar (1.02 individuals). Also the results in Table (1) revealed that, the potato cultivars were arranged descendingly according to their susceptibility to potato leafhopper, E. decipiens as follow: Spunta (11.25 individuals/ leaf), Cara (8.56 individuals/ leaf), Herms (6.58 individuals/ leaf), Diamante (3.77 individuals/ leaf) and Banba (3.64 individuals/ leaf). The mean numbers of $M$. persicae ranged between 5.74 individuals / leaf in Spunta cultivar to 1.53 individuals/leaf in Diamante cultivar while the Cara cultivar recorded the highest number of cotton aphids (3.37 individuals). Generally, the obtained results in Table (1) showed that, the tested potato cultivars had significant variation in their susceptibility to the infestation by the sucking insect complex. Spunta cultivar was the most susceptible one because it was harbored the highly numbers of the piercing sucking insect pests especially leafhopper than the other cultivars while the Diamante cultivar was the lowest sensitivity cultivar.

Coexistence of sucking pests on different cultivars of potato plants on the summer plantation:

Data presented in Table (1) summarized the coexistence of five sucking insect pests infesting five potato cultivars during the summer plantation of 2017 season. The insects showed variable population densities and coexistence percentages. The most common and dominant sucking insect pests on Herms, Banba and Cara was the whitefly, $B$. tabaci, which was represented by 43.7, 34.98 and $32.77 \%$, respectively, followed by the leafhoppers, which was represented by $32.82,27.2$ and $31.55 \%$, respectively, of the total sucking insects population. Meanwhile, the most abundant sucking pest on Spunta and Diamante cultivars was the leafhopper, E. decipiens which coexisted by 38.47 and $36.43 \%$, followed by B. tabaci $(27.05 \%$ and 34.78$)$ of the total population of sucking insects. Meanwhile the species of $T$. tabaci which had low values of dominance degrees $(3.35,3.39,3.49,4.25$ and $5.46 \%$ in Cara, Herms, Spunta, Diamante and Banba, respectively) is expected to be of little economic importance as it may cause a minor role as a pest in potato plantations.

Table 1. Seasonal mean numbers (and coexistence \%) of certain sucking insect pests on different potato plant cultivars at Beheira Governorate during the summer plantation of 2017:

\begin{tabular}{lcccccc}
\hline Cultivar & B. tabaci & T. tabaci & E. decipiens & A. gosypii & M. persicae & General mean \\
\hline \multirow{2}{*}{ Herms } & $8.76 \pm 0.96^{\mathrm{a}}$ & $0.68 \pm 0.158^{\mathrm{ab}}$ & $6.58 \pm 0.76^{\mathrm{b}}$ & $1.66 \pm 0.16^{\mathrm{b}}$ & $2.37 \pm 0.41^{\mathrm{bc}}$ & $20.05 \pm 1.99^{\mathrm{b}}$ \\
& $(43.7)$ & $(3.39)$ & $(32.82)$ & $(8.27)$ & $(11.82)$ & $(100 \%)$ \\
\hline \multirow{2}{*}{ Banba } & $4.68 \pm 0.55^{\mathrm{b}}$ & $0.73 \pm 0.161^{\mathrm{ab}}$ & $3.64 \pm 0.55^{\mathrm{bc}}$ & $1.56 \pm 0.18^{\mathrm{b}}$ & $2.77 \pm 0.27^{\mathrm{b}}$ & $13.37 \pm 1.46^{\mathrm{c}}$ \\
& $(34.98)$ & $(5.46)$ & $(27.2)$ & $(11.66)$ & $(20.7)$ & $(100 \%)$ \\
\hline \multirow{2}{*}{ Spunta } & $7.91 \pm 0.72^{\mathrm{a}}$ & $1.02 \pm 0.174^{\mathrm{a}}$ & $11.25 \pm 0.95^{\mathrm{a}}$ & $3.32 \pm 0.4^{\mathrm{a}}$ & $5.74 \pm 0.63^{\mathrm{a}}$ & $29.24 \pm 2.16^{\mathrm{a}}$ \\
& $(27.05)$ & $(3.49)$ & $(38.47)$ & $(11.35)$ & $(19.63)$ & $(100 \%)$ \\
\hline \multirow{2}{*}{ Cara } & $8.89 \pm 0.77^{\mathrm{a}}$ & $0.91 \pm 0.178^{\mathrm{a}}$ & $8.56 \pm .97^{\mathrm{b}}$ & $3.37 \pm 0.41^{\mathrm{a}}$ & $5.4 \pm 0.56^{\mathrm{ab}}$ & $27.13 \pm 2.3^{\mathrm{a}}$ \\
& $(32.77)$ & $(3.35)$ & $(31.55)$ & $(12.42)$ & $(19.9)$ & $(100 \%)$ \\
\hline \multirow{2}{*}{ Diamante } & $3.6 \pm 0.33^{\mathrm{c}}$ & $0.44 \pm 0.088^{\mathrm{b}}$ & $3.77 \pm 0.57^{\mathrm{c}}$ & $1.01 \pm 0.18^{\mathrm{b}}$ & $1.53 \pm 0.23^{\mathrm{c}}$ & $10.35 \pm 1.22^{\mathrm{c}}$ \\
& $(34.78)$ & $(4.25)$ & $(36.43)$ & $(9.76)$ & $(14.78)$ & $(100 \%)$ \\
\hline F 0.05 & 12.419 & 2.088 & 17.363 & 14.208 & 17.7 & 19.44 \\
\hline L.S.D. & 1.98155 & 0.4412 & 2.2133 & 0.8 .199 & 1.2769 & 5.3247 \\
\hline
\end{tabular}

Means followed by the same letter(s) within the same column are nonsignificantly different $(P \leq 0.05)$



Fig. 1. Susceptibility of different potato plant cultivars to certain sucking insect pests at Beheira Governorate during the summer plantation of 2017

The same trend of infestation was recorded on the $2^{\text {nd }}$ season, 2018 with slightly variation, the obtained results
(Table $2 \&$ Fig. 2) indicated that there were no significant differences $(P>0.05)$ in the mean numbers of $B$. tabaci among Herms, Spunta and Cara varieties, then, the highest mean number of whitefly infestation was recorded on Herms (5.42 individual/ leaf) followed by Spunta (4.42 individual/ leaf). Concerning the leafhopper, E. decipiens the tested cultivars could be arranged in descending order according to intensity of infestation as follow: Spunta, Herms, Cara, Banba and Diamante, respectively. The highest significant differences $(P<0.05)$ in the mean of infestation of the green peach aphid, $M$. persicae and leafhopper, E. decipiens were recorded between Spunta and Diamante. On the other hand, the data in Table (2) showed that, generally Spunta cultivar recorded the highest infestation by $M$. persicae through the period of study (6.11 individual/leaf) while Cara cultivar (4.34 individual/leaf) come in the second order. The lowest infestation with $M$. persicae (2.32) and A. gosypii (0.93 individual / leaf) was in Diamante Cultivar while Cara cultivar was the highest susceptibility cultivar to infestation with A. gosypii (2.35). 
Data presented in Table (2) and illustrated in Fig. (2) showed that the coexistence of sucking pests on different cultivars of potato cultivars on the $2^{\text {nd }}$ season, 2018, E. decipiens seems to be the most important economic pests on all the tested cultivars except Banba, it made up 37.77, $39.48,32.48$ and $34.19 \%$ of the total piercing sucking insect complex in Herms, Spunta, Cara and Diamante cultivars, respectively. The green peach aphid had high abundance degrees (27.32, 27.47, 25.73 and 28.54) in Banba, Spunta, Cara and Diamante cultivars, respectively. Also, Table 3 shows that the B. tabaci made up 34, 28.32, 24.6, 22.63 and 19.87 of the total insect pests on Herms, Banba, Cara, Diamante and Spunta respectively.

Table 2. Seasonal mean numbers (and coexistence \%) of certain sucking insect pests on different potato plant cultivars at Beheira Governorate during the summer plantation of 2018:

\begin{tabular}{|c|c|c|c|c|c|c|}
\hline Cultivar & B. tabaci & T.tabaci & E. decipiens & A. gosypii & M. persicae & General mean \\
\hline Herms & $\begin{array}{c}5.42 \pm 0.95^{\mathrm{a}} \\
(34)\end{array}$ & $\begin{array}{c}0.25 \pm 0.05^{\mathrm{c}} \\
(1.57)\end{array}$ & $\begin{array}{c}6.02 \pm 0.78^{\mathrm{ab}} \\
(37.77)\end{array}$ & $\begin{array}{c}1.18 \pm 0.19^{\mathrm{cd}} \\
(7.4)\end{array}$ & $\begin{array}{c}3.07 \pm 0.47^{\mathrm{bc}} \\
(19.26)\end{array}$ & $\begin{array}{c}15.92 \pm 2.2^{b} \\
(100 \%)\end{array}$ \\
\hline Banba & $\begin{array}{c}3.11 \pm 0.58^{\mathrm{bc}} \\
(28.32)\end{array}$ & $\begin{array}{c}0.33 \pm 0.07^{b} \\
(3)\end{array}$ & $\begin{array}{c}3.07 \pm 0.53^{b} \\
(27.96)\end{array}$ & $\begin{array}{c}1.47 \pm 0.14^{\mathrm{bcd}} \\
(13.39)\end{array}$ & $\begin{array}{l}3 \pm 0.59^{\mathrm{bc}} \\
(27.32)\end{array}$ & $\begin{array}{c}10.98 \pm 1.75^{\mathrm{bc}} \\
(100 \%)\end{array}$ \\
\hline Spunta & $\begin{array}{c}4.42 \pm 0.59^{\mathrm{ab}} \\
(19.87)\end{array}$ & $\begin{array}{c}0.9 \pm 0.16^{\mathrm{a}} \\
(4.05)\end{array}$ & $\begin{array}{c}8.78 \pm 0.88^{\mathrm{a}} \\
(39.48)\end{array}$ & $\begin{array}{c}2.03 \pm 0.32^{\mathrm{ab}} \\
(9.13)\end{array}$ & $\begin{array}{c}6.11 \pm 0.97^{\mathrm{a}} \\
(27.47)\end{array}$ & $\begin{array}{c}22.24 \pm 2.31^{\mathrm{a}} \\
(100 \%)\end{array}$ \\
\hline Cara & $\begin{array}{c}4.15 \pm 0.49^{\mathrm{ab}} \\
(24.6)\end{array}$ & $\begin{array}{c}0.55 \pm 0.13^{b} \\
(3.26)\end{array}$ & $\begin{array}{c}5.48 \pm 0.84^{\mathrm{ab}} \\
(32.48)\end{array}$ & $\begin{array}{c}2.35 \pm 0.28^{\mathrm{a}} \\
(13.93)\end{array}$ & $\begin{array}{c}4.34 \pm 0.74^{\mathrm{ab}} \\
(25.73)\end{array}$ & $\begin{array}{c}16.87 \pm 2.3^{\mathrm{ab}} \\
(100 \%)\end{array}$ \\
\hline Diamante & $\begin{array}{c}1.84 \pm 0.34^{\mathrm{c}} \\
(22.63)\end{array}$ & $\begin{array}{c}0.26 \pm 0.07^{\mathrm{bc}} \\
(3.2)\end{array}$ & $\begin{array}{c}2.78 \pm 0.88^{b} \\
(34.19)\end{array}$ & $\begin{array}{c}0.93 \pm 0.12^{\mathrm{d}} \\
(11.44)\end{array}$ & $\begin{array}{c}2.32 \pm 0.37^{\mathrm{c}} \\
(28.54)\end{array}$ & $\begin{array}{c}8.13 \pm 1.19^{c} \\
(100 \%)\end{array}$ \\
\hline $\mathrm{F}_{0.05}$ & 4.792 & 6.805 & 11.18 & 6.846 & 5.15 & 7.535 \\
\hline L.S.D. & 1.77 & 0.29905 & 2.08095 & 0.6411 & 1.8764 & 5.66935 \\
\hline
\end{tabular}

Means followed by the same letter(s) within the same column are nonsignificantly different $(P \leq 0.05$



Fig. 2. Susceptibility of different potato plant cultivars to certain sucking insect pests at Beheira Governorate during the summer plantation of 2018

Co-existents of predacious insects in potato varieties:

Results in Tables (3-4) showed that, predatory insect species found on potato plants cultivars during two seasons, 2017 and 2018 in summer plantation. During the $1^{\text {st }}$ season (Table 3), the overall mean population of the green lacewing in potato cultivars was 4.61, 3.55, 3.16, 2.91 and 2.65 / plant in Spunta, Diamante, Cara, Banba and Herms, respectively. The highest mean number of the seven spotted lady beetle $C$. septempunctata was recorded in Spunta cultivar (2.48) while the lowest mean number of this species was recorded in Diamante (1.11 individuals/ plant). On the other hand, the overall mean population of $C$. undecimpunctata were 2.04, 1.87, 1.4, 1.3 and 0.82 per plant on Spunta, Cara, Banba, Herms and finally Diamante, respectively. The population of Orius $s p$ varied non-significantly $\left(\mathrm{F}_{0.05}=1.713\right)$ with potato cultivars where's the overall mean population of Orius $s p$ were 1.52 individuals/plant in Spunta cultivar followed by 1.13, 1.11, 0.84 and 0.71 in Cara, Diamante, Herms and Banba, respectively.

The same trend was repeated on the $2^{\text {nd }}$ season (Table 4) where's the Spunta cultivar harbored the highest numbers of C. carnea (4.38), C. septempunctata (2.41), C. undecimpunctata (1.55) and Orius sp (1.32 individuals / plant). Followed by Cara cultivar $(2.75,1.36,1.13$ and 0.76 for $C$. carnea, $C$. septempunctata, $C$. undecimpunctata and Orius sp., respectively). The lowest mean of population density of $C$. carnea (1.32 individual / plant) was recorded in Herms cultivars while the lowest means population of $C$. septempunctata (2.41) and C. undecimpunctata (1.55) were recorded in Diamante cultivar.

Table 3. Coexistence of certain predatory insects on different potato cultivars at Beheira Governorate during the summer plantation of 2017:

\begin{tabular}{|c|c|c|c|c|c|}
\hline Cultivar & C. carnea & C. septempunctata & C. undecimpunctata & Orius sp & General mean \\
\hline Herms & $\begin{array}{c}2.65 \pm 0.53^{b} \\
(42.13)\end{array}$ & $\begin{array}{c}1.4 \pm 0.4^{\mathrm{ab}} \\
(22.26)\end{array}$ & $\begin{array}{c}1.4 \pm 0.29^{\mathrm{ab}} \\
(22.26)\end{array}$ & $\begin{array}{c}0.84 \pm 0.17^{\mathrm{ab}} \\
(13.35)\end{array}$ & $\begin{array}{c}6.29 \pm 1.34 \\
(100 \%)\end{array}$ \\
\hline Banba & $\begin{array}{c}2.91 \pm 0.57^{b} \\
(46.41)\end{array}$ & $\begin{array}{c}1.35 \pm 0.34^{\mathrm{ab}} \\
(21.53)\end{array}$ & $\begin{array}{c}1.3 \pm 0.29^{\mathrm{ab}} \\
(20.73)\end{array}$ & $\begin{array}{c}0.71 \pm 0.2^{b} \\
(11.32)\end{array}$ & $\begin{array}{c}6.26 \pm 1.28 \\
(100 \%)\end{array}$ \\
\hline Spunta & $\begin{array}{c}4.61 \pm 0.93^{\mathrm{a}} \\
(43.29)\end{array}$ & $\begin{array}{c}2.48 \pm 0.55^{\mathrm{a}} \\
(23.29)\end{array}$ & $\begin{array}{c}2.04 \pm 0.52^{\mathrm{a}} \\
(19.15)\end{array}$ & $\begin{array}{c}1.52 \pm 0.32^{\mathrm{a}} \\
(14.27)\end{array}$ & $\begin{array}{c}10.65 \pm 2.22 \\
(100 \%)\end{array}$ \\
\hline Cara & $\begin{array}{c}3.16 \pm 0.83^{\text {ab }} \\
(38.54)\end{array}$ & $\begin{array}{c}2.03 \pm 0.51^{\mathrm{a}} \\
(24.76)\end{array}$ & $\begin{array}{c}1.87 \pm 0.3^{\mathrm{a}} \\
(22.8)\end{array}$ & $\begin{array}{c}1.14 \pm 0.26^{\mathrm{ab}} \\
(13.9)\end{array}$ & $\begin{array}{c}8.2 \pm 1.66 \\
(100 \%)\end{array}$ \\
\hline Diamante & $\begin{array}{c}3.55 \pm 0.81^{\text {ab }} \\
(53.87)\end{array}$ & $\begin{array}{c}1.11 \pm 0.21^{b} \\
(16.84)\end{array}$ & $\begin{array}{c}0.82 \pm 0.15^{b} \\
(12.44)\end{array}$ & $\begin{array}{c}1.11 \pm 0.22^{\mathrm{ab}} \\
(16.84)\end{array}$ & $\begin{array}{c}6.58 \pm 1.3 \\
(100 \%)\end{array}$ \\
\hline $\mathrm{F}_{0.05}$ & 1.035 & 1.803 & 2.088 & 1.713 & 1.38 \\
\hline L.S.D. & 1.6737 & 1.19655 & 0.95325 & 0.6787 & 4.5505 \\
\hline
\end{tabular}

Means followed by the same letter(s) within the same column are nonsignificantly different $(P \leq 0.05)$ 
Darwish, A. A. E.

Table 4. Coexistence of certain predatory insects on different potato plant cultivars at Beheira Governorate during the summer plantation of 2018:

\begin{tabular}{|c|c|c|c|c|c|}
\hline Cultivar & C. carnea & C. septempunctata & C. undecimpunctata & Orius $s p$ & General mean \\
\hline \multirow{2}{*}{ Herms } & $1.32 \pm 0.38^{b}$ & $1.03 \pm 0.3^{\mathrm{b}}$ & $0.67 \pm 0.22$ & $0.74 \pm 0.2$ & $3.75 \pm 0.97^{b}$ \\
\hline & $(35.11)$ & $(27.39)$ & $(17.82)$ & $(19.68)$ & $(100 \%)$ \\
\hline \multirow{2}{*}{ Banba } & $2.37 \pm 0.53^{\mathrm{ab}}$ & $1.29 \pm 0.29^{\mathrm{ab}}$ & $0.84 \pm 0.24^{\mathrm{ab}}$ & $0.62 \pm 0.18$ & $5.11 \pm 1.13^{b}$ \\
\hline & $(46.29)$ & $(25.2)$ & $(16.41)$ & $(12.11)$ & $(100 \%)$ \\
\hline \multirow{2}{*}{ Spunta } & $4.38 \pm 1.03^{\mathrm{a}}$ & $2.41 \pm 0.67^{\mathrm{a}}$ & $1.55 \pm 0.39$ & $1.32 \pm 0.28$ & $9.65 \pm 2.2^{\mathrm{a}}$ \\
\hline & $(45.34)$ & $(24.95)$ & $(16.04)$ & $(13.66)$ & $(100 \%)$ \\
\hline \multirow{2}{*}{ Cara } & $2.75 \pm 0.76^{\mathrm{ab}}$ & $1.36 \pm 0.37^{\mathrm{ab}}$ & $1.13 \pm 0.38$ & $0.76 \pm 0.2$ & $6 \pm 1.58^{\mathrm{ab}}$ \\
\hline & $(45.83)$ & $(22.67)$ & $(18.83)$ & (12.67) & $(100 \%)$ \\
\hline \multirow{2}{*}{ Diamante } & $2.46 \pm 0.78^{\mathrm{ab}}$ & $0.96 \pm 0.17^{b}$ & $0.64 \pm 0.18$ & $1.15 \pm 0.33$ & $5.21 \pm 1.22^{b}$ \\
\hline & $(47.22)$ & $(18.43)$ & $(12.28)$ & $(22.07)$ & $(100 \%)$ \\
\hline$\overline{\mathrm{F}_{0.05}}$ & 2.28 & 2.14 & 1.639 & 1.523 & 2.238 \\
\hline L.S.D. & 2.08105 & 1.1323 & 2.081 & 0.689 & 4.223 \\
\hline
\end{tabular}

Means followed by the same letter(s) within the same column are nonsignificantly different $(P \leq 0.05)$

\section{DISCUSSION}

The crop cultivars that are resistant to insect pests considered one of the most important items in integrated pest management system. Resistance cultivars may be less preferred by insects because their effect on the survival and normal development of these insects (Hoffman and Frodsham, 1993). The resistance cultivars have been used greatly day after day to avoid the use chemical insecticides and their toxic effect. Many studies have investigated the susceptibility of different cultivars of different crops to several piercing insect pests such as Musa et al. (2004) who studied the sensitivity of two potato cultivars (Romano and Desiree) to M. persicae and Mogahed, (2015) who studied the sensitivity of Nicola and Spunta cultivars to aphids, jassids and whitefly. Silva et al. (2008) evaluated the resistance of 24 potato genotypes to $B$. tabaci in five greenhouse experiments. They found that the cultivar Achat was the most resistant while clone NYL 235-4 was the most susceptible to B. tabaci.

Although no any cultivar showed $100 \%$ resistance against the sucking insect pests, the hypothesis of the planned work was verified on the present results that the different cultivars of potato plants have different resistance capacity against piercing sucking insect pests. Throughout the study, the most susceptible cultivar was Spunta followed by Cara; whereas, Diamante showed more resistance against sucking insect complex as compared to the other tested cultivars tested. In general, the mean number of whiteflies and leafhopper populations were more abundant compared to that of thrips or aphids populations. These results are in harmony with those recorded by Mogahed, 2015 who found that each of the leaf hopper, E. discipiens and white fly, $B$. tabaci were more present on the potato plants than other piercing pests. In Pakistan, Ali, et al. (2011) found that the population density of aphids per leaf of potato plants was more abundant than leafhopper and whitefly population before the treatment with some chemical against the aphids, jassids and whiteflies.

The results revealed that the maximum green peach aphid's population was observed on Spunta followed by Cara and were statistically similar to each other, while the minimum green peach aphids population was observed on Diamante cultivar. Musa et al. (2004) in Kosovo, found that the highest number of $M$. persicae was recorded on potato plants var. Romano (16.8 as average number of aphids/100 leaves), whereas the lowest number of this species was recorded on potato plants var. Desiree (2.2 aphids/100 leaves). Fréchette, et al. (2009) found that the wild potato more resistant to $M$. persicae than the commercially cultivated S. tuberosum cv. Désirée. Mahmoud, et al., 2011 studied the host preference of potato leaf hopper, E. decipiens from six plant species and find that the potato plants was the $2^{\text {nd }}$ preferred host to this insect after broad bean plant and followed by squash, Pea, green bean and finally lupine. During this study the Spunta cultivar was the most susceptible for this insect while diamante was the less preferred potato cultivars. On the whole, it is clear that the total numbers of the B. tabaci, T. tabaci, E. decipiens and A. gosypii on the different cultivars were more abundant during the $1^{\text {st }}$ season than the $2^{\text {nd }}$ season. On the contrary, the green peach aphid was more abundant during the $2^{\text {nd }}$ season than $1^{\text {st }}$ season. These levels of infestation between the two seasons might be attributed to the differences in the weather factors. Also, the previous results revealed that the green lacewing, $C$. carnea; seven-spotted lady beetle, $C$. septempunctata; eleven spotted lady beetle, $C$. undecimpunctata and the pirate bug, Orius sp were the most important predators in the potato plants. The green lacewing, $C$. carnea was the most prevailing pests on potato plant cultivars representing from 38.54 to $53.87 \%$ and from 35.11 to $47.22 \%$ of the total predators in the different cultivars during the $1^{\text {st }}$ and $2^{\text {nd }}$ seasons, respectively. In this respect, Sherief, et al. 2013 in sugar beet plants at Zagazig district in Sharkia Governorate found that the $C$. carnea represented about 54.75 and 45.05 $\%$ of the total predators in $1^{\text {st }}$ and $2^{\text {nd }}$ season, respectively. While these results are in disagreement with Hamouda (1993) who stated that the chrysopid predator represented $5.5-10.2 \%$ while the coccinellid predator species represented $78.5-90.1 \%$ of the total predator species in vegetable crops.

\section{CONCLUSION}

In this study, differences were observed among five global potato cultivars regarding their susceptibility to attack by five piercing sucking insect pests. This report shows that the most susceptible cultivars were Spunta and Cara. Banba and Diamante cultivars were found quite resistance to piercing sucking insect pests while Herms cultivar was found as moderately susceptible. Both of $C$. carnea, $C$. septempunctata, $C$. undecimpunctata and Orius $\mathrm{sp}$ are the most important predators associated with piercing sucking insect pests in the potato cultivars.

\section{REFERENCES}

Abdel-Aal, Z.S.; A. Khalf-Alla; M. Al-Shal, and M. Abd-alQader (1977): "Vegetables Production" Part 2. Dar. Al-Madboat. Al-Jadida, Publisher Alexandria, A.R.E. pp. 15-57. 
Ali H.; R.A. Shah; Q. Zeb, H. Badshah and M. Rehman (2011): Evaluation of some chemicals against the aphids, jassids and whiteflies in potato. Sci. Int. (Lahore), 23(1): 67-69.

Cloyd R.A. and C.S. Sadof (1998): Aphids: Biology and Management. Floriculture Indiana. 12(2): 3-7.

D'Auria, E.M.; C.H. Wohleb; T.D. Waters and D.W. Crowder (2016): Seasonal population dynamics of three potato pests in Washington state. Environmental Entomology, 45(4): 781-789

El-khawas M.A.M. and M.A. Shoeb (2004): Population fluctuation of the major sap sucking insects and associated natural enemies on potato Bull. Ent. Soc. Egypt, 81; 209-219

Fernandes F.L. and M. E. de S. Fernandes (2015): Flight movement and spatial distribution of immune marked thrips in onion, potato, and tomato, Pesq. agropec. bras., Brasília, 50(5): 399-406

Fréchette B.; M. Bejan; É. Lucas; P. Giordanengo and C. Vincent (2009): Resistance of wild Solanum accessions to aphids and other potato pests in Quebec field conditions. Journal of Insect Science, $10(161) ; 1-16$

Greathead, A.H., (1986): Host plants. In: Bemisia tabaci A Literature Survey on the Cotton Whitefly with an Annotated Bibliography. Cook, M. J. W. (Ed.), CAB. International. London, pp: 17-26

Hamouda, S.H.H.; F.K. Aly, and M.S. Fouad, (2001): Relative abundance of sucking insects and their predators on different plant densities of black cumin and coriander and the estimation of injury threshold and yield loss. Minia J. Agric. Res. \& Dev., 21(2): 315-332

Hoffman, M.P. and A. Frodsham, (1993): Natural Enemies of Vegetable Insect Pests Comparative Extension. Cornell University Press, Ithica, USA, ISBN-13: 9781577532521, pp: 63

Hooker W.J. (1986): Compendium of potato diseases. The APS, 3340 Pilot Knob Road, St. Paul, Minnesota 55121, USA: $125 \mathrm{p}$

Lamp W.O.; G.R. Nielsen and S.D. Danielson (1994): Patterns among host plants of potato leafhopper, Empoasca fabae (Homoptera: Cicadellidae). J. Kans Entomol Soc. 67(4):354-378

Mahmoud, Y.A.; E.M. Amr, and I.M.A. Ebadah, (2011): Some Ecological Behaviors of the Leafhopper, Empoasca decipiens (Paoli) on Some Winter Plantations in Egypt. J. Basic. Appl. Sci. Res., 1(2) 88-94

Mogahed M.I. (2015): Evaluation the Role of Intercropping Culture in Protection of Potato Plants under Fruit Trees Against Some Sucking Insect Pests and its Relation with Productivity. International Journal of Techno Chem Research. 01, 03, pp 165-174
Mogahed, M.I. (2000): Effect of intercropping culture on the population of insect pests attacking potato varieties (Alpha \& Draga). Conference of Social and Agricultural Development of Sinai, 16-19

Musa, M.F.; C. Carli; L.R. Susuri and I.M. Pireva (2004): Monitoring of Myzus persicae (Sulzer) in potato fields in Kosovo. Acta agriculturae slovenica, 83(2): 379- 385

Nderitu, J.H. and J.M. Mueke (1986): Aphid infestation on eight potato cultivers (Solanum toberosum L.) in Kenya. Insect Science and its Application. 7(5): 677682

Raman, K.V. (1984). Monitoring aphid populations. CIP Slide Training Series IV-2. International Potato Center, Lima, Peru: $12 \mathrm{p}$.

Saguez J. R.; R. Hainez and A. Cherqui (2005): Unexpected effect of chitinases on the peach -potato aphid (Myzus persicae Sulzer) When delivered via transgenic potato plants (Solanum tuberosum Linne) and in vitro. Transgenic Research, 14; 57-67

Saguez J.; A. Cherqui; S. Lehraiki; C. Vincent; A. Beaujean; L. Jouanin; J. C. Laberche and P. Giordanengo (2010): Effect of mti-2 Transgenic potato plants on the aphid Myzus persicae) Sternorrhyncha: Aphididae). International Journal of Agronomy, Article ID 653431, 7;66

SAS Institute, Inc. (1999): PC - SAS users guide, Version 8. North Carolina statistical analysis sys-tem Institute, Inc.

Sharma H.C. and R. Ortiz (2001): Host plant resistance to insects: An eco-friendly approach for pest management and environment conservation. Journal of Environmental Biology 23(2):111-135

Sherief, E.A.H.; A.A.A. Said; F.A.H. Shaheen and H.A.M. Fouad (2013): Population fluctuation of certain pests and their associated predator insects on sugar beet in Sharkia Governorate, Egypt. Egypt. J. Agric. Res., 91(1):139-150

Silva M.S.; A.L. Lourencao; Souza-Dias Jac; H.S. Miranda Filho; V.J. Ramos; E.A. Schammass (2008): Resistance of potato genotypes (Solanum spp.) to Bemisia tabaci biotype B. Horticultura Brasileira 26: 221-226

Visser R.G.F.; C.W.B. Bachem; J.M. de Boer; G.J. Bryan; S.K. Chakrabati; S. Feingold; R. Gromadka; R.C.H.J. van Ham; S. Huang; J.M.E. Jacobs; B. Kuznetsov; P.E. de Melo; D. Milbourne; G. Orjeda; B. Sagredo and X. Tang (2009): Sequencing the Potato Genome: Outline and First Results to Come from the Elucidation of the Sequence of the World's Third Most Important Food Crop. American Journal of Potato Research. 86, 417-429

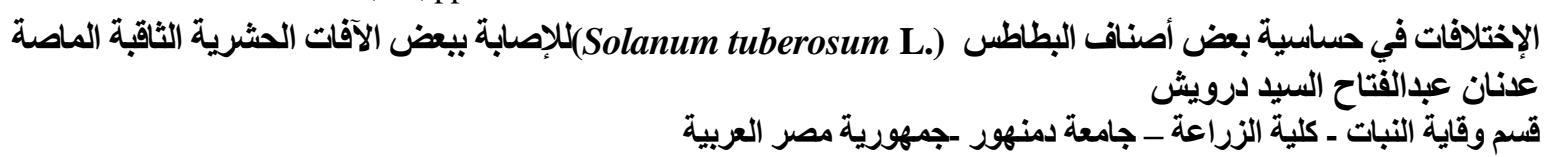

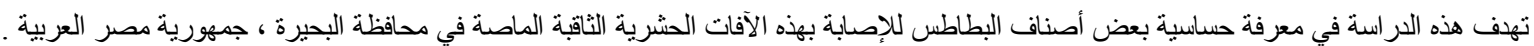

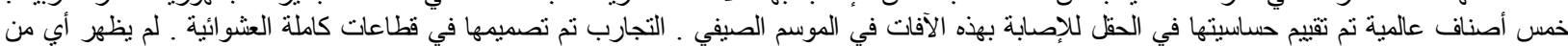

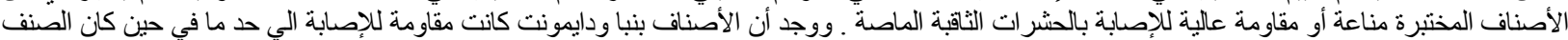

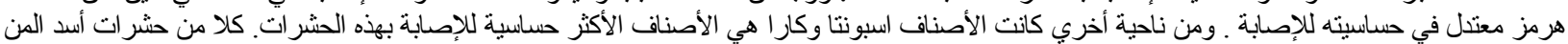

Carnea المفترسات الحشرية السائده و الهامة المصاحبة للحشرات الثاقبة الماصة في مختلف الأصناف 